Отримано: 11 липня 2018 р.

Прорецеензовано: 29 липня 2018 р.

Прийнято до друку: 04 вересня 2018 р.

e-mail: y.v.pasich@gmail.com

DOI: 10.25264/2311-5149-2018-10(38)-105-109
Пасічник Ю. В. Сукупний державний борг україни: загрози та наслідки. Наукові записки Начіонального університету «Острозька академія». Серія «Економіка» : науковий журнал. Острог : Вид-во НаУОА, вересень 2018. № 10(38). С. 105-109.

\author{
Пасічник Юрій Васильович, \\ доктор економічних наук, професор кафедри фінансів \\ Національного університету біоресурсів і природокористування Украӥни
}

JEL Classification: E 58: E 63: G 17: $H$ 63: $H 68$

\title{
СУКУПНИЙ ДЕРЖАВНИЙ БОРГ УКРАЇНИ: ЗАГРОЗИ ТА НАСЛІДКИ
}

У статті з'ясовано специфіку формування й обслуговування державного та гарантованого державою боргу України. Виконано аналіз динаміки боргу Украӥни та витрат на його обслуговування. Порівняно співвідношення державного боргу Украӥни й інших країн до ВВП. Виявлено загрози від зростаючих обсягів иього боргу й обумовлено наслідки за трьома сиенаріями. Розроблено конкретні рекомендації щодо його обслуговування.

Ключові слова: державний і гарантований державою борг, загрози та наслідки боргу.

\author{
Пасичник Юрий Васильевич, \\ доктор экономических наук, профессор кафедры финансов \\ Наиионального университета биоресурсов и природопользования Украиньл
}

\section{СОВОКУПНЫЙ ГОСУДАРСТВЕННЫЙ ДОЛГ УКРАИНЫ: УГРОЗЫ И ПОСЛЕДСТВИЯ}

В статье выяснена специффика формирования и обслужсивания государственного и гарантированного государством долга Украины. Выполнен анализ динамики долга Украины и расходов на его обслуживание. Сравненно соотношение государственного долга Украины и других стран к ВВП. Выявлено угрозы растущих объемов этого долга и обусловлены последствия за тремя сиенариями. Разработаны конкретные рекомендации по его обслуживанию.

Ключевые слова: государственный и гарантированный государством долг, угрозы и последствия долга.

\section{Yurii Pasichnyk,}

Doctor of Economics, professor at the department of finance,

National University of Life and Environmental Sciences of Ukraine

\section{TOTAL GOVERNMENT STATE DEBT OF UKRAINE: THREATS AND CONSEQUENCES}

Realities of the contemporary world confirm the importance of external borrowings, In the case of Ukraine the meaning of external debt is quite special, despite the increasing volumes and, correspondingly, threats and complex consequences.

The Aim of this article is to identify the government-guaranteed debt growth threats on social development and to substantiate theoretical approaches to decrease these threats. The main research method systemic allows to explore complex unbalanced systems, which Ukraine now is. The article reveals the specificity of the formation and maintenance of the stateguaranteed debt of Ukraine. The author provides the analysis of the debt dynamics and the cost of its services in relation to GDP in Ukraine and selected countries of the world. The author develops specific recommendations for the debt service, discovers public threats in the political, economic and social spheres. Provided the excess in the Maastricht criteria comparing 2014, , which provides for the top face relative to percent of debt to GDP not over 60, forms a significant dependence on the creditors, including the default, in an unstable and weak economy has a certain probability. A comparison of this criterion with Japan, Italy and other countries is incorrect, despite the economic power of these countries and a significant difference in social functioning. Also a permanent intervention of the major creditors, particularly the IMF on the direction of reforms, including in the social sphere, not always adequately reflects the Ukrainian reality and invokes the correspondent social disturbance.

The author implements a public debt forecast for both pessimistic probability and the optimal scenarios. The results of the study confirm the feasibility of priority development of the economy in order to reduce the debt burden. The implementation of this important task is a prerequisite for the reduction of threats and negative effects of public debt permanent growth.

Key words: state and state guaranteed debt, threats and consequences of debt.

Постановка проблеми. Сучасний світ є непередбачуваним і мінливим, а процеси глобалізації формують відповідні умови існування держав. Фінансова складова у функціонуванні окремих країн завжди була визначальною, тому що забезпечувала суспільний розвиток, зокрема і добробут громадян. Сучасні світові реалії підтверджують вагомість зовнішніх запозичень, а щодо України - їх значення є доволі особливим, зважаючи на зростаючі обсяги, загрози і складні наслідки. 
Аналіз останніх досліджень і публікацій. Беручи до уваги вагомість цієї проблематики не лише для України, але й інших зарубіжних країн, їі досліджували зарубіжні та вітчизняні вчені. Серед зарубіжних учених, які з'ясовували ці проблеми у другій половині XX ст. - П. Барро, Дж. Б'юкенен, Р. Девіс, Ф. Модільяні, М. Фрідман, а на початку ХХІ ст. - Н. Афлатет [1; 2], С. Арданья, Ф. Каселлі, Т. Лейн [3], Г. Бон [4], С. Пападаму, М. Сідіропулос, Е. Спіромітрос [5]. Відповідні дослідження в Україні виконували: О. Дем'янчук [6], Л. Лисяк [7], Ю. Макогон [8], А. Молчанова [ 9], К. Філоненко [10] та інші.

Проте, незважаючи на вагомі дослідження зарубіжних і вітчизняних науковців, проблеми формування, наслідків і специфіка загроз державного боргу є перманентно актуальними для всіх країн, беручи до уваги мінливість світового простору. Щодо України, то в період складних суспільних процесів, які $\epsilon$ характерними для сучасних реалій, ця проблематика також $є$ важливою.

Метою статті є виявлення наслідків зростання державного та гарантованого державою боргу на суспільний розвиток, а також обгрунтування теоретичних підходів щодо зменшення загроз.

Виклад основного матеріалу. Забезпечення стабільного розвитку будь-якої держави обумовлюється, передусім, економічною складовою. В сучасних реаліях України слабкість реальної економіки не продукує динамічний суспільний поступ, тому виникають проблеми освітнього, медичного, пенсійного, житлово-комунального зрізу. Однією з характеристик стабільної економіки $є$ стан фінансової системи, зокрема сукупного державного боргу України, від якого безпосередньо залежить бюджетна спроможність, стабільність національної валюти, функціонування фондового ринку, розвиток малого і середнього бізнесу тощо. Для з'ясування стану сукупного державного боргу та виконання аналізу наслідків його впливу на суспільний розвиток співставимо відповідні індикатори. Зазначимо, що борг держави у класифікаційний ознаках визначено Бюджетним кодексом України (рис.1).

Отже, структура боргу та боргових зобов'язань має відповідні виміри. Проаналізуємо динаміку формування цього боргу та витрати на його обслуговування (таблиця 1). Також порівняємо співвношення державного боргу до ВВП в Україні й окремих країнах світу (рис. 2).

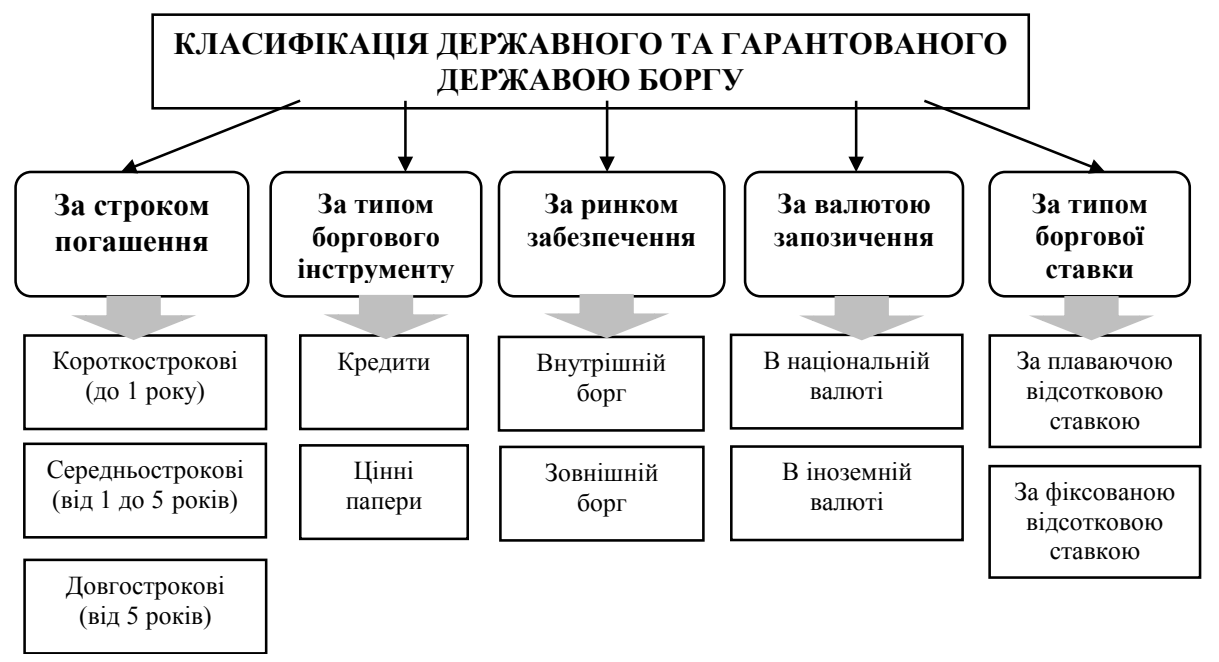

Рис. 1. Класифікація сукупного боргу України

Джерело: складено за [11].

Державний та гарантований державою борг України (млрд грн)

\begin{tabular}{|c|c|c|c|c|c|c|c|}
\hline \multirow{2}{*}{ Роки } & \multicolumn{3}{|c|}{ Борг } & \multirow{2}{*}{ ВВП } & \multirow{2}{*}{$\begin{array}{c}\text { Держборг загаль- } \\
\text { ний, \% до ВВП }\end{array}$} & \multicolumn{2}{|c|}{ Обслуговування } \\
\hline & Внутрішній & Зовнішній & Загальний & & & Обсяги & \% до доходів ДБУ \\
\hline 2009 & 105,1 & 211,6 & 316,9 & 913,3 & 34,7 & 9,0 & 4,3 \\
\hline 2010 & 155,5 & 276,7 & 432,2 & 1082,6 & 39,9 & 15,5 & 6,5 \\
\hline 2011 & 173,7 & 299,4 & 473,1 & 1316,6 & 35,9 & 23,1 & 7,4 \\
\hline 2012 & 206,5 & 309,0 & 515,5 & 1408,9 & 36,6 & 24,5 & 7,0 \\
\hline 2013 & 284,1 & 300,0 & 584,1 & 1454,9 & 40,1 & 31,7 & 9,3 \\
\hline 2014 & 488,9 & 611,7 & 1100,5 & 1566,7 & 70,2 & 48,0 & 13,4 \\
\hline 2015 & 529,5 & 1042,7 & 1572,2 & 1979,5 & 79,4 & 84,5 & 16,3 \\
\hline 2016 & 689,7 & 1240,0 & 1929,8 & 2383,2 & 81,0 & 95,8 & 15,8 \\
\hline 2017 & 766,7 & 1375,0 & 2141,7 & 2982,3 & 71,8 & 110.5 & 14,3 \\
\hline 2018 план) & $\mathrm{X}$ & $\mathrm{X}$ & 2744,8 & $\mathrm{X}$ & $X$ & 130.2 & 14,2 \\
\hline
\end{tabular}

Джерело: складено автором за $[12,13,14]$. 


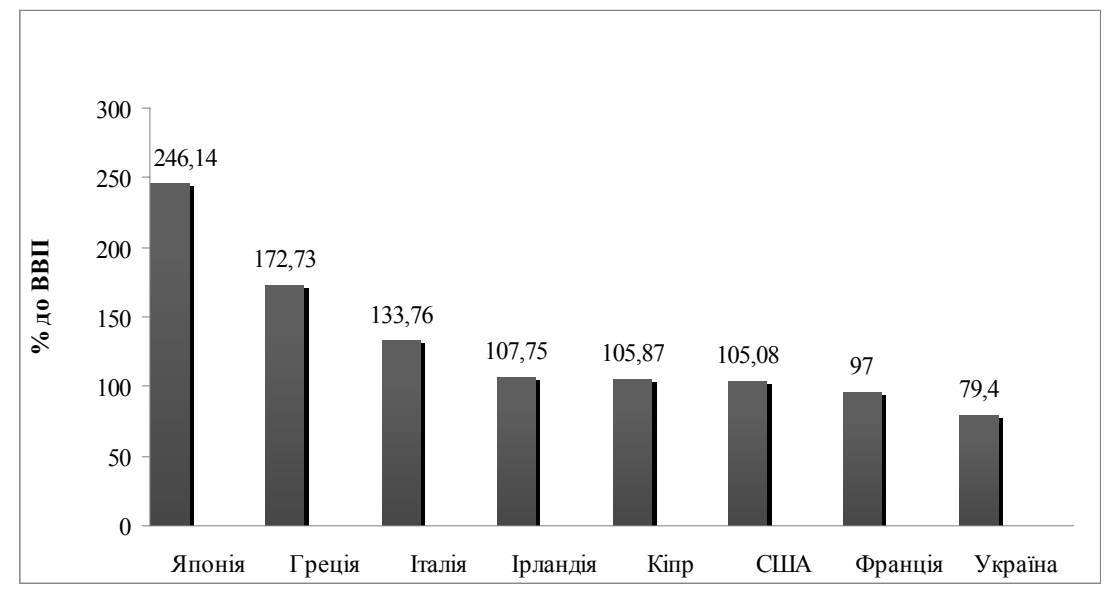

Рис. 2. Співставлення державного боргу до ВВП в Україні й інших країнах у 2015 р.

Джерело: складено за $[14 ; 15]$.

Використовуючи результати експрес-аналізу щодо боргу України, виявимо суспільні загрози у відповідних сферах.

\section{Політична:}

- зростаюча залежність від урядів країн і міжнародних організацій, які є кредиторами, зокрема щодо рекомендацій до призначення вищих посадовців;

- підлеглість щодо вирішення геополітичних проблем.

Економічна:

- суттєвий негативний вплив на функціонування всієї реальної економіки. У цьому контексті Прем'єрміністр України В. Гройсман зауважив: «Найбільша проблема з економічної точки зору - це тиск на державу зовнішніх боргів, велика частина яких була накопичена до 2014 року» [16];

- перевищення з 2014 р. маастрихтського критерію, який передбачає верхню межу щодо відсотків боргу до ВВП не більше 60, формує значну залежність від кредиторів, зокрема і дефолту, що в умовах нестабільної та слабкої економіки має певну ймовірність. Співставлення цього критерію з Японією, Італією й іншими країнами $є$ некоректним, зважаючи на економічну могутність цих країн і суттєву відмінність у суспільному функціонуванні;

- перманентне зростання боргу в розрахунку на 1 особу з 1,9 тис. грн у 2008 р. до 12.7 тис. грн у 2014 р. та більше ніж 47 тис. грн у 2018 р. [12; 14; 17] формує психологічну залежність боржника, як принизливого індивідуума із неусвідомленим відчуттям втрати життєво важливого;

- різноманітні фінансові ризики, враховуючи бюджетний, валютний, фондовий, страховий, підприємницький тощо.

\section{Соціальна:}

- зростаючі виплати на обслуговування та погашення боргу та ризики неотримання рефінансування зумовлюють низькі соціальні стандарти в пенсійному, медичному, освітньому пільговому тощо забезпеченні;

- перманентне втручання основних кредиторів, зокрема МВФ, щодо напрямів реформ, зокрема і в соціальній сфері, не завжди адекватно відображає українські реалії та викликає відповідні соціальні збурення.

Ці та інші загрози не сприяють стабілізації суспільної ситуації та не формують підвалини економічного зростання.

Зважаючи на виявлені загрози обгрунтуємо можливі сценарії наслідків щодо ситуаціх із цим боргом.

Песимістичний. Беручи до уваги нестабільну соціальну ситуацію та загрозливі обсяги запозичень під час погіршення ситуації в Україні може бути дефолт. Водночас, зважаючи на певний прогрес у реформах та відповідну політичну підтримку наших міжнародних партнерів, він $є$ малоймовірним.

Ймовірнісний. Зважаючи на слабкість реальної економіки, негативні суспільні тренди, зокрема рівень корупції, несприятливий бізнесовий клімат, в тому числі для малого і середнього підприємництва, небажання зовнішніх інвесторів працювати в Україні, трудову міграцію в інші прикордонні країни, неефективність та млявість реформ та інші проблеми та зважаючи на інертність процесів розвитку протягом 2 - х або 3 - х років можливе зростання боргів і лише за умови активізації суспільних реформ відбудеться стабілізація із подальшим зменшенням заборгованості. 
Оптимальний. Беручи до уваги стабільні темпи зростання ВВП, які фіксуються за останні роки на рівні $3 \%$, певну довіру міжнародних кредиторів, величезні потенційні можливості України $є$ вірогідність поліпшення ситуації та зменшення заборгованості, проте такий сценарій можливий лише за надзвичайно сприятливих обставин, зокрема і списання частини боргу. Так, С. Рибалка, виконавши дослідження, зазначає: «У різні періоди списували чи реструктуризували борги таких країн: Аргентини, Бразилії, Коста-Рики, Марокко, Мексики, Філіппін, Венесуели. Наприклад, у 2004-2008 рр. за ініціативою США було списано 4,1 млрд дол. Іраку. Згодом Паризький клуб ухвалив рішення поетапного списання цій країні 80\% боргу, на суму понад 30 млрд дол. У 2005 р. і 2010 р. Аргентина відтермінувала 93\% зовнішніх боргів, обмінявши старі боргові папери на нові з дисконтом $70 \%$. У підсумку заборгованість країни зменшилась приблизно на 65 млрд дол. У 2012 р. Греція реструктуризувала свій борг обсягом 350 млрд. дол., а понад 100 млрд. євро, які уряду позичали європейські приватні банки, були списані. Відповідно до звіту МВФ, до березня 2016 р. кандидатами на списання боргу є 36 країн. Переважно це країни Африки, Латинської Америки та Карибського басейну на суму близько 76 млрд дол. [18]. Зауважимо, що фахівцями Міністерства фінансів України здійснено прогноз зменшення державного боргу до 2045 р. Так, якщо у 2019 р. необхідно витратити на обслуговування та погашення 326 млрд грн, то вже у 2020 p. - 284 млрд грн, у 2025 р. - 160 млрд грн, у 2030 р. - 94 млрд грн, у 2040 р. 25 млрд грн, і у 2045 р. - 17 млрд грн [12].

Отже, реалізація конкретного сценарію залежить від зусиль усього суспільства i, насамперед, від державних адміністративних структур.

Нині у фаховій літературі як вітчизняній, так і зарубіжній, висвітлюють конкретні концепції, моделі, методи управління державним боргом, проте державний борг є наслідком функціонування суспільної системи, тому для його зменшення необхідно підвищувати ефективність цієї системи, з пріоритетом економічної. Неодхідно активізувати суспільні реформи в комплексі, тому що зміни в судовій, медичній, пенсійній, освітній тощо сферах повинні адекватно реалізовуватись із економічними. Саме економічна система має надавати відповідні ресурси, зокрема фінансові, для всієї суспільної. Реформи, які у свій час реалізовувались у США, Німеччині, південно-азійських країнах базувались на активізації реальної економіки, створенні нових робочих місць, забезпеченні сприятливих умов для бізнесу тощо. Зазначимо, що Польща, яка наприкінці 2017 р. мала рекордний профіцит бюджету в розмірі 4,9 млрд злотих (\$1,36 млрд. дол. США) та темпи економічного зростання 4\%, відмовилась від кредитної лінії МВФ на суму $\$ 9,2$ млрд дол. США [18].

Зростання економіки, зокрема збільшення iï потенціалу, є найважливішою умовою забезпечення суспільного розвитку і зменшення державного боргу. У контексті реалізації фінансового потенціалу О. Дем'янчук зазначає: «...фінансовий потенціал адміністративно-територіальної одиниці залежить від рівня розвитку реального сектора економіки території та потенційних можливостей ії економічного зростання в умовах створення нових суб' єктів господарювання різних організаційно-правових форм власності, а також суттєвого зменшення рівня тінізації економіки як адміністративно-територіальної одиниці, так і країни в цілому» [6]. Саме на забезпечення економічного зростання повинні бути спрямовані дії Президента України, Верховної Ради України, Кабінету Міністрів України із залученням громадських організацій і фахівців.

Висновки. Отже, результати виконаного дослідження підтверджують доцільність пріоритетного розвитку економіки для зменшення боргового тягаря. Реалізація цого важливого завдання є умовою зменшення загроз і негативних наслідків перманентного зростання обсягів державного боргу. Необхідно також узагальнити, проаналізувати й оптимально застосувати зарубіжний досвід - як в історичному зрізі, так і сучасний, зокрема Польщі, для формування відповідної парадигми щодо державного боргу. Зважаючи на актуальність цісї проблеми для України, доцільно залучити до ії вирішення, окрім фахівців державних структур, науковий потенціал закладів Міністерства освіти та науки і Національних академій наук.

\section{Література:}

1. Afflatet, N. (2013). Politik, Staatsverschuldung und die deutsche Schuldenbremse [Politics, public debt and the German debt brake]. Frankfurt am Main.

2. Afflatet, N. (2016). Public debt and borrowing: Are governments disciplined by financial markets? Cogent Economics \& Finance, Vol. 4 - Issue 1.

3. Ardagna, S., Caselli, F., \& Lane, T. (2007). Fiscal discipline and the cost of public debt service: Some estimates for OECD countries. The BE Journal of Macroeconomics, 7(1), 1-33.

4. Bohn, H. (2011). The Economic consequences of rising U. S. government debt: Privileges at risk. FinanzArchiv: Public Finance Analysis, 67, 282-302.

5. Papadamou, S., Sidiropoulos, M., \& Spyromitros, E. (2012). Does central bank independence affect public debt? Society of Policy Modeling (Working Paper). Heraklion: University of Crete.

6. Дем'янчук О. І. Складові фінансового потенціалу адміністративно-територіальної одиниці. Наукові записки Наиіонального університету «Острозька академія». Серія «Економіка» : збірник наукових праць / ред. 
кол. : І. Д. Пасічник, О. І. Дем’янчук. - Острог : Видавництво Національного університету «Острозька академія», 2014. Випуск 25. С. 95-103.

7. Лисяк Л.В. Боргова політика України в умовах реформування системи публічних фінансів. Економічний вісник університету: 3б. наук. пращьь. - 2015. Вип. 27/1. С.189-195.

8. Макогон Ю. В. Зовнішній борг України на сучасному етапі економічної кризи. Економічний вісник НТУУ «КПІ»: 3б. наук. пращь. 2016. № 13. С. 108-113.

9. Молчанова А. Ю. Державний борг України: механізм управління та обслуговування. Актуальні проблеми економіки та управління в умовах системної кризи. Львів: МАУП. 2016. С. 40-42.

10. Філоненко К. М. Державний борг України: аналіз динаміки та структури. Статистика України. 2015. № 2. С. 31-34.

11. Бюджетний кодекс України. URL: https://minfin.com.ua/zakon.rada.gov.ua/go/2456-17. (Дата звернення : 2 серпня 2018 р.).

12. Офіційний сайт Міністерства фінансів України. URL: https://index.minfin.com.ua/. (Дата звернення : 2 серпня 2018 р.).

13. Офіційний сайт Державної служби статистики України. URL: http://www.ukrstat.gov.ua/.(Дата звернення : 3 серпня 2018 р.).

14. Государственный и гарантированный государством долг Украины. URL: https://index.minfin.com.ua/. (Дата звернення : 3 серпня 2018 р.)

15. Японія очолила Топ-20 країн з найбільшим держборгом. Дзеркало тижня, 28 липня, 2015. URL: https:// dt.ua/ECONOMICS/yaponiya-ocholila-top-20-krayin-z-naybilshim-derzhborgom-180088_html. (Дата звернення : 2 серпня 2018 р.)

16. Гройсман розповів про найбільшу економічну проблему України. Бізнес, 20 квітня, 2018 p. URL: https:// biz.nv.ua/ukr/economics/hrojsman-rozpoviv-pro-najbilshu-ekonomichnoji-problemi-ukrajini-2465364.html. (Дата звернення : 2 серпня 2018 р.)

17. Рибалка С. Борги України: потрібне списання. Економічна правда. 4 квітня 2017. URL: https://www. epravda.com.ua/columns/2017/04/4/623454. (Дата звернення : 1 серпня 2018 р.)

18. Польща відмовилася від кредиту МВФ на \$9,2 млрд. Ексnрессо, 15 жовтня 2017 p. URL: https:/espreso. tv/news/2017/10/15/polscha_vidmovylasya_vid_kredytu_mvf_na_9_2_mlrd. (Дата звернення : 3 серпня 2018 р.) 